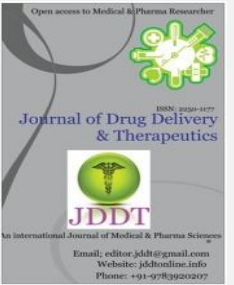

Research Article

\title{
METHOD DEVELOPMENT AND ITS VALIDATION FOR QUANTITATIVE DETERMINATION OF BOSENTAN IN TABLET DOSAGE FORM BY RP-HPLC
}

\author{
*Shahul Hameed M, Jat R. K., Indulatha V. N. \\ Institute of pharmacy, Shri Jagdish Prasad Jhabarmal Tibrewala University, Vidyanagari, Jhunjhunu, Rajasthan, India-333001
}

\begin{abstract}
Objectives of this research work were development and validation of HPLC methods of analysis for Bosentan in tablet dosage form from single components as per the current ICH \& USP guidelines. HPLC methods also validated for the marketed Bosentan from single components. This developed procedure applied for regular analysis of these medicaments in pharmaceutical industry The major scope of research is development of simple, accurate, reproducible $\&$ fast cost effective methods for new cefalosporins. The methods are validated with recovery studies using bulk drug of $80 \%, 120 \%$ \& $40 \%$. Specific method is confirmed by checking interference of excipients \& assay method. The interday \& intraday assay is also performed for checking robustness of the system. The minimum detection limit is checked by using formula LOD = 3.3 sigma (Standnd deviation) / Slop, where $\sigma$ indicate standard deviation \& $\mathrm{S}$ denotes slop of the regression straight line. The quantification limit is determined by using $\mathrm{LOQ}=10 \sigma \quad(\mathrm{St} \&$. dev. $) /$ $\mathrm{S}$ that is minimum concentration of drug can be quantified. Linearity is found in the limit of Beer's law, straight line was constructed within the given range of the conc. of the drugs. So can develop \& validate a new, reproducible, correct, \& easy, less time consuming, cheap \& eco-friendly method for daily analysis of drug in our general life.
\end{abstract}

Keywords: Bosentan, RP HPLC, method development and validation.

Article Info

Received Feb 21, 2017; Review Completed March 07, 2017; Accepted March 15, 2017; Available online March 15, 2017

Cite this article as:

*Shahul HM, Jat RK, Indulatha VN, Method development and its validation for quantitative determination of bosentan in tablet dosage form by RP-HPLC, Journal of Drug Delivery and Therapeutics. 2017; 7(2):85-95. DOI: http://dx.doi.org/10.22270/jddt.v7i2.1409

*Address for Correspondence

Shahul Hameed M, Institute of pharmacy, Shri Jagdish Prasad Jhabarmal Tibrewala University, Vidyanagari, Jhunjhunu, Rajasthan, India-333001, Email: shahulqa@gmail.com

\section{INTRODUCTION}

Bosentan is used to treat pulmonary hypertension by blocking the action of endothelin molecules that would otherwise promote narrowing of the blood vessels and lead to high blood pressure. Metabolism of Bosentan occurs mainly in the liver by the action of cytochrome $\mathrm{P}$ (CYP) $450 \quad 3 \mathrm{~A} 4$ and 2C9, which produces three metabolites: the hydroxylated (hydroxy) metabolite, the demethylated (phenol) metabolite and the hydroxylated and demethylated (hydroxy-phenol) metabolite ${ }^{1-4}$. Bosentan is chemically, 4-tert-butyl-N-[6-(2hydroxyethoxy) -5- (2-methoxyphenoxy) -2- (pyrimidin2-yl) pyrimidin-4-yl] benzene-1 sulfonamide ${ }^{5}$. Various liquid chromatography techniques have been developed for the determination of bosentan in biological fluids ${ }^{6-7}$ and tablet dosage forms ${ }^{8}$. Karnaker RT, et al. (2010) reported RPHPLC procedure for the development \& validation of Bosentan present in tab. formulations. The mobile phase was selected on the hit $\&$ trial basis. The run time for mobile phase is $1 \mathrm{ml} /$ minutes \& gradient technique was used for continue elution of mobile phase according to volume time ratio ${ }^{8}$. 
<smiles>COc1ccccc1Oc1c(NS(=O)(=O)c2ccc(C(C)(C)C)cc2)nc(-c2ncccn2)nc1OCCO</smiles>

The method was developed for bulk drug $\&$ then applied for pharmaceutical formulations. The method is validated for recovery studies $(40,80,120 \%)$, linearity, (preparation of standard curve), detection of limit, limit of quantification, stability studies on temperature basis, specificity of instruments. The method was applied for routine analysis of drugs ${ }^{10}$.

In the present study a simple, rapid, precise and accurate stability indicating liquid chromatographic method was developed for the determination of BST in in tablet dosage forms and validated as per ICH guidelines.

\section{MATERIAL AND METHODS:}

\section{Analytical Method Development ${ }^{10,11}$}

\subsection{Equipments}

The following instruments \& equipments were used during the development studies:

Table 1: List of Equipments

\begin{tabular}{|l|l|}
\hline HPLC instrument & $\begin{array}{l}\text { Waters 2695 separations module with 2487/2489 dual wavelength absorbance } \\
\text { detector with Empower chromatographic software. }\end{array}$ \\
\hline pH meter & Thermo-Orion star series \\
\hline Analytical balance & Mettler Toledo \\
\hline Ultrasonic bath & POWER SONIC420 “Aarkey" \\
\hline Water purification System & Milli Q Gradient A 10,Elix A 10 "Millipore” \\
\hline
\end{tabular}

\subsection{Reagents \& Chemicals}

The following reagents $\&$ chemicals were used during the validation studies:

Table 2: List of reagents

\begin{tabular}{|c|l|l|l|}
\hline Sr. No. & \multicolumn{1}{|c|}{ Name of the material } & Grade & Make \\
\hline 1 & Potassium Dihydrogen ortho Phosphate & ExcelaR & Fisher Scientific \\
\hline 2 & Methanol & HPLC & S.D. Fine \\
\hline 3 & Acetonitrile & HPLC & Rankem \\
\hline 4 & Water & HPLC & Inhouse \\
\hline
\end{tabular}

\subsection{Working Standard}

The following Working standard was used during the develop studies:

Bosentan in Salt form: Potency (\%) 98.8

\subsection{Parameter Wise Method Development Plan}

\section{A. Molecular weight:}

Molecular weight of Bosentan is $321.82 \mathrm{gm} \mathrm{\&} \mathrm{in} \mathrm{salt}$ form molecular weight is $419.7 \mathrm{gm}$.

B. Column selection: Non-polar columns
C. Detector selection: Bosentan is a UV active compound. Therefore, UV detector has been chosen for detection.

D. Selection of wavelength: $\lambda_{\max }$ of Bosentan is $220 \mathrm{~nm}$.

E. Mobile phase selection: In mobile phase preparation following solvent $\&$ buffer has been taken:

a) Acetonitrile is used as it is having the UV-cut off $190 \mathrm{~nm} \&$ is commonly used solvent.

b) Phosphate buffer was selected as buffer: $1.36 \mathrm{gm}$ potassium di-hydrogen phosphate in $1 \mathrm{~L}$ Milli Q Water (pH Value-4.4) 


\subsection{Method Development Trials}

Table 3: Trial no. 1 Chromatographic conditions

\begin{tabular}{|l|l|}
\hline Column & $\begin{array}{l}\text { Inertsil ODS-3V } \\
(150 * 4.6) \mathrm{mm}, 5 \mu \mathrm{m}\end{array}$ \\
\hline Flow rate & $1.0 \mathrm{ml} / \mathrm{min}$ \\
\hline Detector wavelength & $220 \mathrm{~nm}$ \\
\hline Injection volume & $10 \mu \mathrm{L}$ \\
\hline Sample temperature & $25^{\circ} \mathrm{C}$ \\
\hline Column temperature & $25^{\circ} \mathrm{C}$ \\
\hline Detector & $\mathrm{UV}$ \\
\hline Diluent & Buffer:ACN $(75: 25)$ \\
\hline Mobile phase B & Acetonitrile \\
\hline Mobile phase A & Buffer \\
\hline Run time & 20 mins. \\
\hline
\end{tabular}

Table 4: Trial no. 2 Chromatographic conditions

\begin{tabular}{|l|l|}
\hline Column & $\begin{array}{l}\text { Kromasil C 18 (150*4.6) } \\
\mathrm{mm}, 5 \mu \mathrm{m}\end{array}$ \\
\hline Sample temperature & $25^{\circ} \mathrm{C}$ \\
\hline Injection volume & $10 \mu \mathrm{L}$ \\
\hline Flow rate & $1.0 \mathrm{ml} / \mathrm{min}$ \\
\hline Detector wavelength & $220 \mathrm{~nm}$ \\
\hline Column temperature & $25^{\circ} \mathrm{C}$ \\
\hline Detector & $\mathrm{UV}$ \\
\hline Composition & Buffer: ACN $(75: 25)$ \\
\hline Mobile phase B & Acetonitrile \\
\hline Mobile phase A & Buffer \\
\hline Run time & 20 mins \\
\hline
\end{tabular}

Table 5: Trial no. 3 Chromatographic conditions

\begin{tabular}{|l|l|}
\hline Column & $\begin{array}{l}\text { Zorbax C 8 }(150 * 4.6) \\
\mathrm{mm}, 5 \mu \mathrm{m}\end{array}$ \\
\hline Sample temperature & $25^{\circ} \mathrm{C}$ \\
\hline Injection volume & $10 \mu \mathrm{L}$ \\
\hline Flow rate & $1.0 \mathrm{ml} / \mathrm{min}$ \\
\hline Detector wavelength & $220 \mathrm{~nm}$ \\
\hline Column temperature & $25^{\circ} \mathrm{C}$ \\
\hline Detector & $\mathrm{UV}$ \\
\hline Diluent & BUFFER:ACN $(75: 25)$ \\
\hline Mobile phase B & Acetonitrile \\
\hline Mobile phase A & BUFFER \\
\hline Run time & 20 mins. \\
\hline
\end{tabular}

Table 6: Trial no. 4 Chromatographic conditions

\begin{tabular}{|l|l|}
\hline Column & $\begin{array}{l}\text { Ultron ES OVM }(150 * 4.6) \\
\mathrm{mm}, 5 \mu \mathrm{m}\end{array}$ \\
\hline Sample temperature & $25^{\circ} \mathrm{C}$ \\
\hline Injection volume & $10 \mu \mathrm{L}$ \\
\hline Flow rate & $1.0 \mathrm{ml} / \mathrm{min}$ \\
\hline Detector wavelength & $220 \mathrm{~nm}$ \\
\hline Column temperature & $25^{\circ} \mathrm{C}$ \\
\hline Detector & UV \\
\hline Diluent & BUFFER:ACN $(60: 40)$ \\
\hline Mobile phase B & Acetonitrile \\
\hline Mobile phase A & BUFFER \\
\hline Run time & 20 mins. \\
\hline
\end{tabular}

Table 7: Trial no. 5 Chromatographic conditions

\begin{tabular}{|l|l|}
\hline Column & $\begin{array}{l}\text { Ultron ES OVM-(150- } \\
4.6) \mathrm{mm}, 5 \mu \mathrm{m}\end{array}$ \\
\hline Sample temperature & $25^{\circ} \mathrm{C}$ \\
\hline Injection volume & $10 \mu \mathrm{L}$ \\
\hline Flow rate & $1.0 \mathrm{ml} / \mathrm{min}$ \\
\hline Detector wavelength & $220 \mathrm{~nm}$ \\
\hline Column temperature & $25^{\circ} \mathrm{C}$ \\
\hline Detector & $\mathrm{UV}$ \\
\hline Coposition & Buffer: ACN $(90: 10)$ \\
\hline Mobile phase B & Acetonitrile \\
\hline Mobile phase A & Buffer \\
\hline \multicolumn{1}{|c|}{ Run time } & 20 mins. \\
\hline
\end{tabular}

Table 8: Trial no. 6 Chromatographic conditions

\begin{tabular}{|l|l|}
\hline Column & $\begin{array}{l}\text { Ultron ES OVM }(150 * 4.6) \\
\mathrm{mm}, 5 \mu \mathrm{m}\end{array}$ \\
\hline Sample temperature & $25^{\circ} \mathrm{C}$ \\
\hline Injection volume & $10 \mu \mathrm{L}$ \\
\hline Flow rate & $1.0 \mathrm{ml} / \mathrm{min}$ \\
\hline Detector wavelength & $220 \mathrm{~nm}$ \\
\hline Column temperature & $25^{\circ} \mathrm{C}$ \\
\hline Detector & $\mathrm{UV}$ \\
\hline Diluent & BUFFER: ACN $(80: 20)$ \\
\hline Mobile phase B & Acetonitrile \\
\hline Mobile phase A & BUFFER \\
\hline Run time & 20 mins \\
\hline
\end{tabular}

Table 9: Trial no. 7 Chromatographic conditions

\begin{tabular}{|l|l|}
\hline Column & $\begin{array}{l}\text { Ultron ES OVM }\left(150^{* 4.6)}\right. \\
\mathrm{mm}, 5 \mu \mathrm{m}\end{array}$ \\
\hline Sample temperature & $25^{\circ} \mathrm{C}$ \\
\hline Injection volume & $10 \mu \mathrm{L}$ \\
\hline Flow rate & $1.2 \mathrm{ml} / \mathrm{min}$ \\
\hline Detector wavelength & $220 \mathrm{~nm}$ \\
\hline Column temperature & $25^{\circ} \mathrm{C}$ \\
\hline Detector & $\mathrm{UV}$ \\
\hline Diluent & BUFFER:ACN $(80: 20)$ \\
\hline Mobile phase B & Acetonitrile \\
\hline Mobile phase A & BUFFER \\
\hline Run time & 20 mins. \\
\hline
\end{tabular}

Table 10: Trial no. 8 Chromatographic conditions

\begin{tabular}{|l|l|}
\hline Column & $\begin{array}{l}\text { Ultron ES OVM }(150 * 4.6) \\
\mathrm{mm}, 5 \mu \mathrm{m}\end{array}$ \\
\hline Sample temperature & $25^{\circ} \mathrm{C}$ \\
\hline Injection volume & $10 \mu \mathrm{L}$ \\
\hline Flow rate & $1.2 \mathrm{ml} / \mathrm{min}$ \\
\hline Detector wavelength & $220 \mathrm{~nm}$ \\
\hline Column temperature & $25^{\circ} \mathrm{C}$ \\
\hline Detector & $\mathrm{UV}$ \\
\hline Diluent & BUFFER:ACN $(80: 20)$ \\
\hline Mobile phase B & Acetonitrile \\
\hline Mobile phase A & BUFFER \\
\hline Run time & 20 mins. \\
\hline
\end{tabular}




\section{Analytical Method Validation}

2.1 Objective: To demonstrate that Assay method of Bosentan by Reverse Phase-high performance liquid chromatography (RP-HPLC) is suitable for intended purpose.

2.2 Scope: This validation study is applicable for Assay method of Bosentan, which will be used to ensure the identity, quality \& purity of active pharmaceutical ingredient.

\subsection{Methodology}

\subsubsection{Preparation of mobile phase-A}

Dissolved 1.36 gm of potassium dihydrogen phosphate to $1000 \mathrm{~mL}$ of HPLC grade water. Mixed well using a magnetic stirrer bar until completely mixed. The solution was filtered through a $0.45 \mu \mathrm{m}$ nylon membrane filter $\&$ degassed.

2.3.2 Preparation of mobile phase-B: Acetonitrile (HPLC Grade)

\subsubsection{Preparation of standard solution}

Weighed accurately about $48 \mathrm{mg}$ of Bosentan working/reference standard into $50 \mathrm{~mL}$ volumetric flask. Dissolve in $30 \mathrm{~mL}$ of Methanol \& dilute to volume with methanol. Diluted $5 \mathrm{ml}$ of this solution to $50 \mathrm{ml}$ Methanol

\subsubsection{Preparation of sample solution}

5 Intact tablet of Bosentan taken into $500 \mathrm{ml}$ volumetric flask than added $10 \mathrm{ml}$ of water \& sonicate till disintegrated. Added about $400 \mathrm{ml}$ of methanol \& sonicated for 45 minutes than made up volume with methanol. Added $5 \mathrm{ml}$ of this solution in to $50 \mathrm{ml}$ volumetric flask \& make up volume with methanol.

\section{System Precision ${ }^{12}$}

\subsection{Chromatographic conditions}

Table 11: Chromatographic conditions

\begin{tabular}{|l|l|}
\hline Column & Ultron ES OVM $(150 * 4.6) \mathrm{mm}, 5 \mu \mathrm{m}$ \\
\hline Sample temperature & $25^{\circ} \mathrm{C}$ \\
\hline Injection volume & $10 \mu \mathrm{L}$ \\
\hline Flow rate & $1.2 \mathrm{ml} / \mathrm{min}$ \\
\hline Detector wavelength & $220 \mathrm{~nm}$ \\
\hline Column temperature & $25^{\circ} \mathrm{C}$ \\
\hline Detector & UV \\
\hline Diluent & BUFFER:ACN $(80: 20)$ \\
\hline Mobile phase B & Acetonitrile \\
\hline Mobile phase A & BUFFER \\
\hline Run time & 20 mins. \\
\hline
\end{tabular}

\subsection{HPLC analysis}

Purge injector, seal wash, needle wash, wet prime \& equilibrate the HPLC system until a steady baseline obtained (at least for 30 minutes) After the system has equilibrated \& delta psi of system is less than 50, inject blank (Single injection), standard solution (5 replicate injection) \& sample solution (in duplicate) into the chromatographic system.

\subsection{Acceptance criteria for system suitability}

1. The percentage relative standard deviation (\%RSD) of drug peak areas for six replicate

Injections of working standard solution should not be more than $2 \%$.

2. The tailing factor of standard peak should not be more than 2.0

3 . The plate count of standard peak should be more than 2000 .

\section{Method Precision:}

Methodology: 5 intact tablet of Bosentan taken into $500 \mathrm{ml}$ volumetric flask than added $10 \mathrm{ml}$ of water \& sonicate till disintegrated. Added about $400 \mathrm{ml}$ of methanol \& sonicated for 45 minutes than made up volume with methanol. Added $5 \mathrm{ml}$ of this solution in to $50 \mathrm{ml}$ volumetric flask \& make up volume with methanol.

The sample was prepared six times as per above methodology \& injected in duplicate into the HPLC system.

\section{Linearity}

Prepared system suitability solution \& diluted standard solution as per STP. Injected blank, system suitability solution \& diluted standard solution as per injection sequence. Checked the acceptance criteria for system suitability.

\subsection{Preparation of Linearity Stock Solution}

Weighed $99.52 \mathrm{gm}$ of working standard in $100 \mathrm{ml}$ volumetric flask. Added $30 \mathrm{ml}$ of methanol \& sonicated to dissolve. Made up volume with methanol.

Prepared Linearity solution of $20 \%, 80 \%, 120 \%$, $160 \%, 240 \%$ by dilution of Linearity Stock solution as below

\section{Conc. $(\mu \mathrm{g} / \mathrm{mL})=$}

Wt. taken (mg) $x$ Volume of Stock Solution taken $(m L) x$ Potency of St\&ard (on as is basis) $x$ (Molecular Weight of Drug ' $X$ ') $x 1000$ $100 \mathrm{~mL} x$ Dilution $(\mathrm{mL}) \quad x \quad$ Molecular Weight of Bosentan salt form $\quad x \quad 100$

Acceptance criteria: Acceptance criteria for system suitability should pass. Correlation coefficient should not be less than 0.990. Linearity has passed as accepted criteria. 


\section{Accuracy}

Prepared system suitability solution \& diluted standard solution as per STP. Injected blank, system suitability solution \& diluted standard solution as per injection sequence. Checked the acceptance criteria for system suitability.

\subsection{Methodology}

Accuracy weighed placebo equivalent as given below $\mathrm{mg}$ of Bosentan tablets \& about $148 \mathrm{mg}$ of Bosentan in salt form in $500 \mathrm{ml}$ of volumetric flask \& dissolved with methanol \& made up volume with methanol. Further diluted $5 \mathrm{ml}$ of above solution in to $50 \mathrm{ml}$ diluents. Filtered with $0.45 \mu$ filter \& injected in to HPLC

For 30\% Accuracy- About $148 \mathrm{mg}$

For 100\% Accuracy- About $493 \mathrm{mg}$

For 200\% Accuracy- About $985 \mathrm{mg}$

\section{RESULTS AND DISCUSSION}

In order to get the increased efficiency of the chromatographic system, the conditions of experiment such as column, column temp, $\mathrm{pH}$ and composition of mobile phase, and detection wavelength were optimized by changing one parameter at a time and keeping the other parameters constant. In RP HPLC method, the primary requirement for developing a method for analysis is that the using different solvents and buffers and columns to get better retention time and theoretical plates, and better cost effective and time saving method than the previously developed methods.

\section{Method Development Trials}

\section{Trial no.-1}

Trials Observations:

- Run time is longer

- Peak is not eluted.

- Base line is not good.

Corrections to next trial: Column need to be changed

Trial no.-2

Trials Observations:

- Run time is longer

- Peak is not eluted.

- Base line is not good.

Corrections to next trial: Column need to be changed

Trial no.-3

\section{Trials Observations:}

- Run time is longer

- Peak is not eluted.

- Base line is not good.

Corrections to next trial: Mobile Phase composition needs to be changed and Column need to be changed

\section{Trial No.4}

Trials Observations:

- Run time is longer

- Peak is not eluted.

- Base line is good.

- Peak might be eluting earlier in dead volume due to increase ratio of Acetonitrile

Corrections to next trial: Mobile Phase Composition needs to be changed

\section{Trial no.-5}

\section{Trials Observations:}

- Base line is good but the retention of the Drug in the column was too much.

- No Sharpness of the peaks.

- Run time is too longer.

- Peak is eluted too late

- Tailing is high

- Plate count is low

Corrections to next trial: Mobile phase composition needs to be changed.

\section{Trial No.6}

Trials Observations:

- Run time is longer

- Peak shape is good

- Base line is good.

- Peak is eluted late.

Corrections to next trial: Flow rate need to be changed and Run time need to be changed

\section{Trial No.7}

Trials Observations:

- Base line is good

- Sharpness of the peaks is fine

- Run time is optimum.

- Retention time is good (earlier)

- Tailing is low

- Plate count is high

Final Optimized Method

Related chromatogram: for Standard Solution

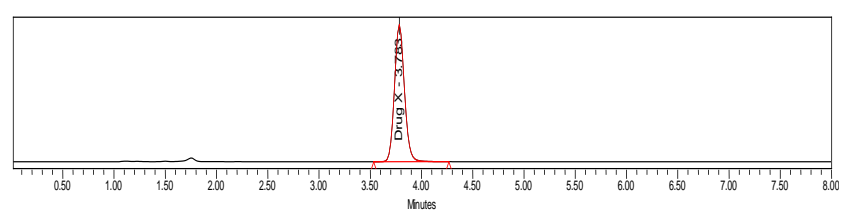

Related chromatogram: for Sample Solution

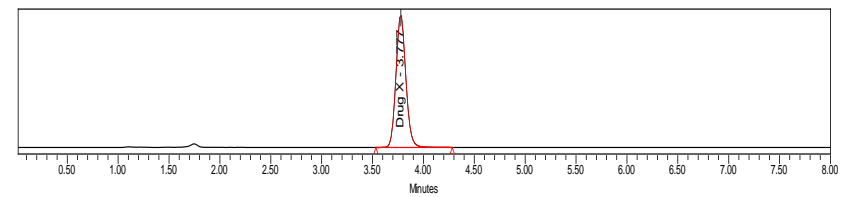




\section{Analytical Method Validation}

Mobile phase-A is prepared by Dissolving $1.36 \mathrm{gm}$ of potassium di hydrogen phosphate to $1000 \mathrm{~mL}$ of HPLC grade water. Mixed well using a magnetic stirrer bar until completely mixed. The solution was filtered through a $0.45 \mu \mathrm{m}$ nylon membrane filter \& degassed. Mobile phase-B is prepared using Acetonitrile (HPLC Grade)

Standard solution is prepared by Weighing accurately about $48 \mathrm{mg}$ of Bosentan working/reference standard into $50 \mathrm{~mL}$ volumetric flask. Dissolve in 30 $\mathrm{mL}$ of Methanol \& dilute to volume with methanol. Diluted $5 \mathrm{ml}$ of this solution to $50 \mathrm{ml}$ Methanol

\section{System Precision}

Table 12: Chromatographic conditions

\begin{tabular}{|l|l|}
\hline Column & Ultron ES OVM $(150 * 4.6) \mathrm{mm}, 5 \mu \mathrm{m}$ \\
\hline Sample temperature & $25^{\circ} \mathrm{C}$ \\
\hline Injection volume & $10 \mu \mathrm{L}$ \\
\hline Flow rate & $1.2 \mathrm{ml} / \mathrm{min}$ \\
\hline Detector wavelength & $220 \mathrm{~nm}$ \\
\hline Column temperature & $25^{\circ} \mathrm{C}$ \\
\hline Detector & UV \\
\hline Diluent & BUFFER:ACN $(80: 20)$ \\
\hline Mobile phase B & Acetonitrile \\
\hline Mobile phase A & BUFFER \\
\hline Run time & 20 mins. \\
\hline
\end{tabular}

\section{Chromatograms of Standard:}

\section{Injection-1}

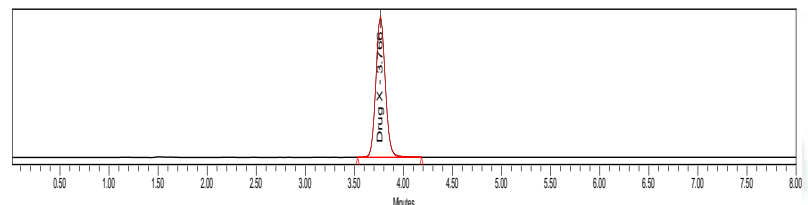

\section{Injection-2}

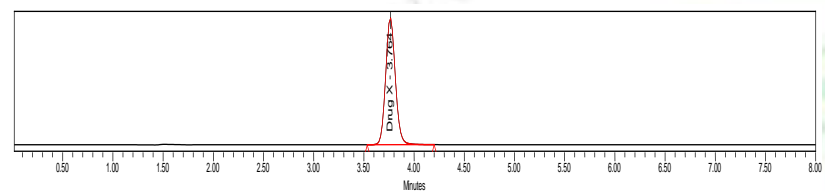

Injection-3

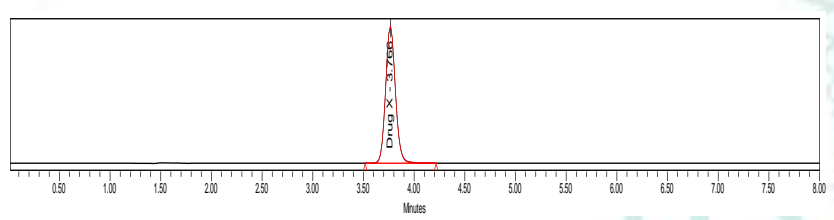

Table 13:

\begin{tabular}{|c|c|}
\hline \multicolumn{2}{|c|}{ Standard Area Counts } \\
\hline Injection & Area \\
\hline 1 & 1926300 \\
\hline 2 & 1937992 \\
\hline 3 & 1938435 \\
\hline 4 & 1934998 \\
\hline 5 & 1940483 \\
\hline 6 & 1938834 \\
\hline Mean & $\mathbf{1 9 3 6 1 7 4}$ \\
\hline S.D. & $\mathbf{5 1 5 6 . 3}$ \\
\hline \% RSD & $\mathbf{0 . 2 7}$ \\
\hline
\end{tabular}

\section{Injection-4}

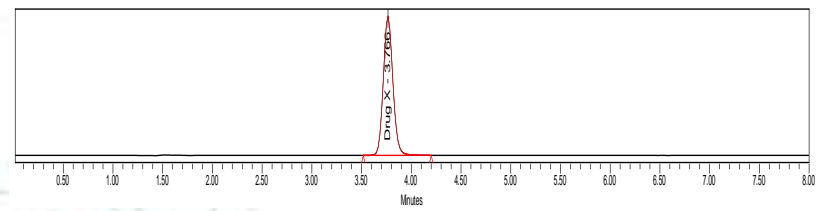

Injection-5

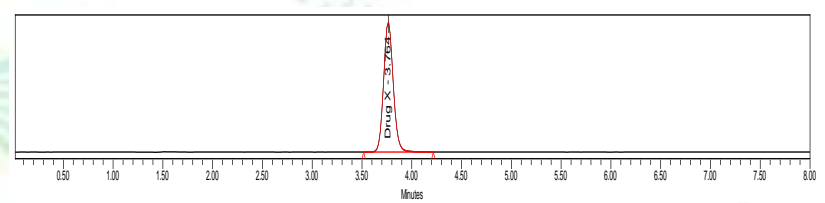

Injection-6

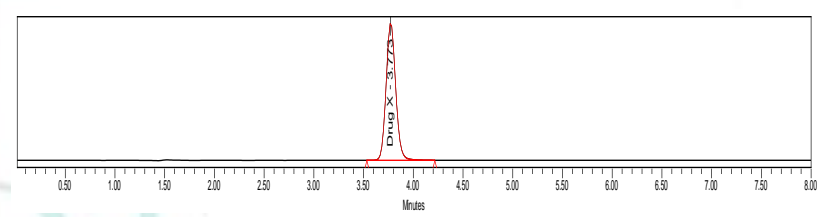

Using the chromatography data acquisition system, integrate the peaks of standard solution.

System suitability passes as per acceptance criteria.

Method Precision:

5 Intact tablet of Bosentan taken into $500 \mathrm{ml}$ volumetric flask than added $10 \mathrm{ml}$ of water \& sonicate till disintegrated. Added about $400 \mathrm{ml}$ of methanol \& sonicated for 45 minutes than made up volume with methanol. Added $5 \mathrm{ml}$ of this solution in to $50 \mathrm{ml}$ volumetric flask \& make up volume with methanol. The sample was prepared six times as per above methodology \& injected in duplicate into the HPLC system. 
Chromatograms of Method Precision

MP-1(Injection-1)

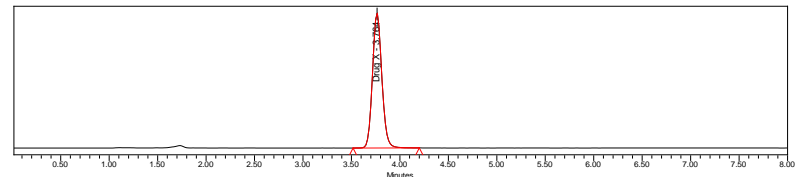

MP-1(Injection-2)

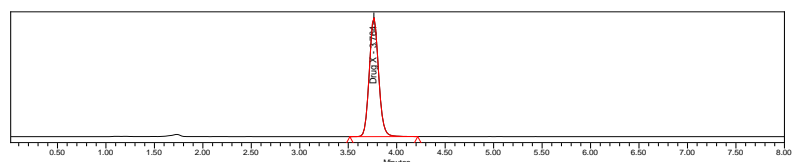

MP-2(Injection-1)

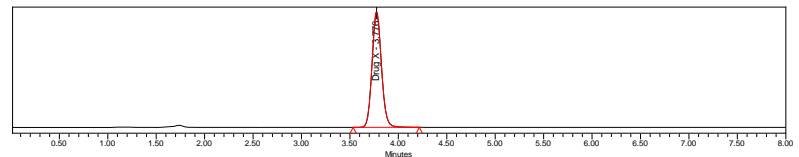

MP-2(Injection-2)

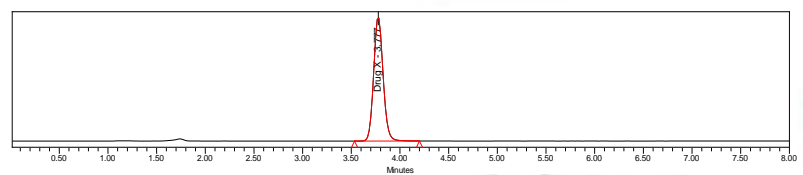

MP-3(Injection-1)

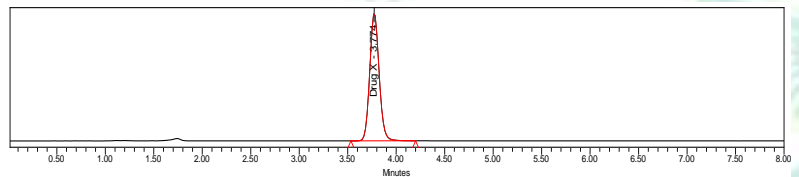

MP-3(Injection-2)

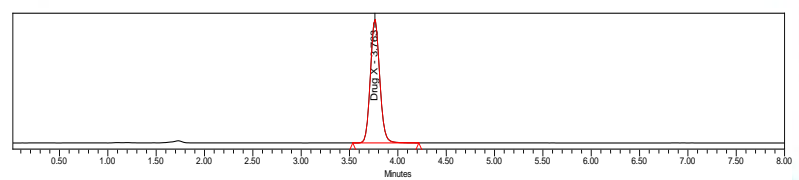

MP-4(Injection-1)

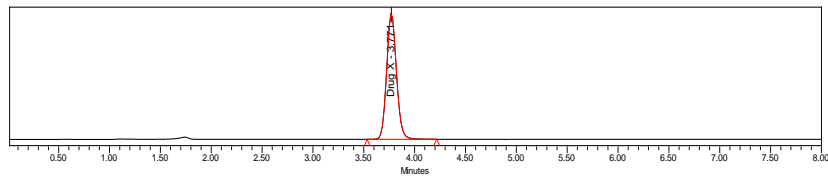

MP-4(Injection-2)

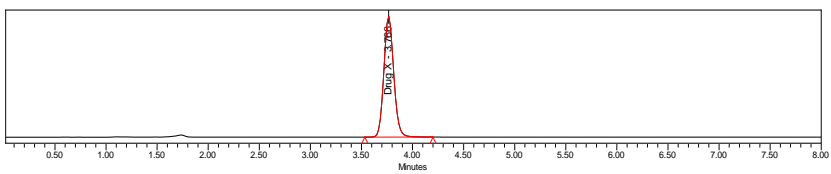

MP-5(Injection-1)

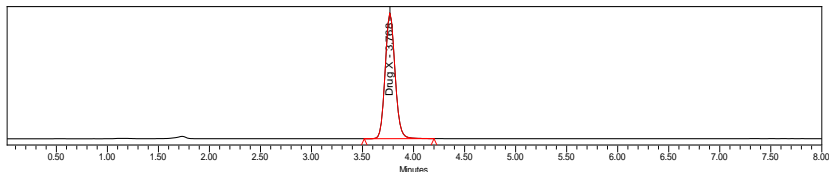

MP-5(Injection-2)

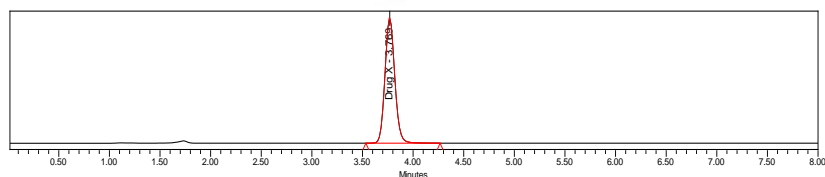

MP-6(Injection-1)

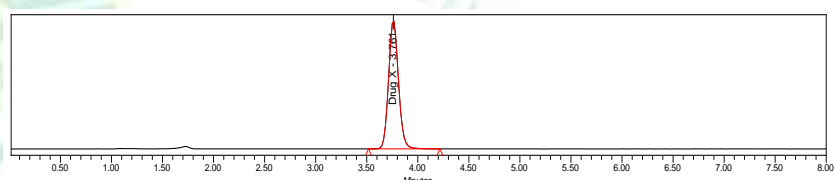

MP-6(Injection-2)

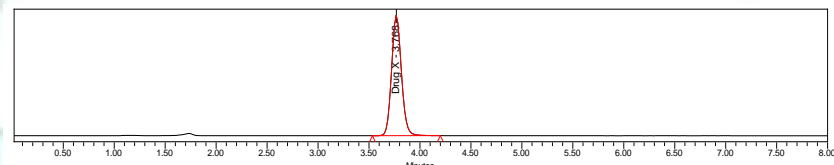

Table 14: Calculation of Method Precision

\begin{tabular}{|c|c|}
\hline \multicolumn{2}{|c|}{ standard Area Counts } \\
\hline Injection & Area \\
\hline 1 & 1926300 \\
\hline 2 & 1937992 \\
\hline 3 & 1938435 \\
\hline 4 & 1934998 \\
\hline 5 & 1940483 \\
\hline Mean & $\mathbf{1 9 3 5 6 4 2}$ \\
\hline S.D. & $\mathbf{5 5 7 7 . 8}$ \\
\hline \% RSD & $\mathbf{0 . 2 9}$ \\
\hline
\end{tabular}

Conclusion: Method Precision has passed as per acceptance criteria. 


\section{Linearity}

Prepared system suitability solution \& diluted standard solution as per STP. Injected blank, system suitability solution $\&$ diluted standard solution as per injection sequence. Checked the acceptance criteria for system suitability.

\section{Chromatogram of Linearity}

Linearity at $20 \%$ ( Injection-1)

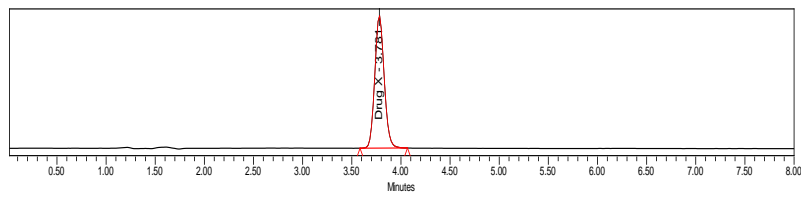

Linearity at $20 \%$ (Injection-2)

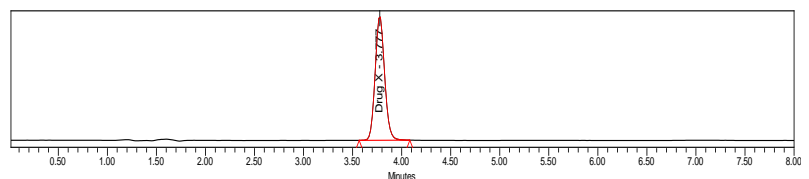

Linearity at $80 \%$ (Injection-1)

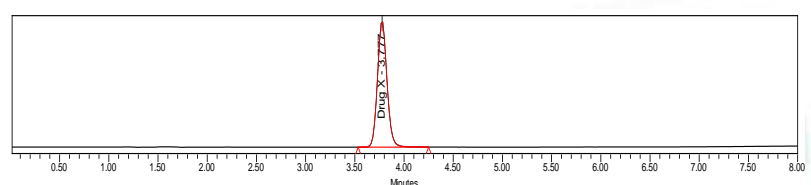

Linearity at $80 \%$ (Injection-2)

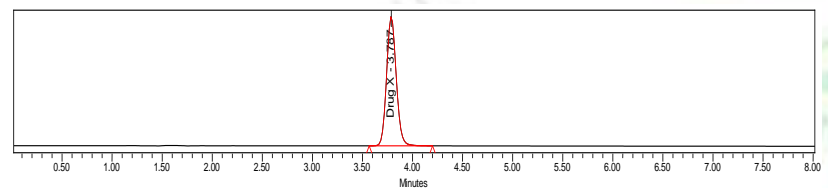

Linearity at $\mathbf{1 2 0 \%}$ (Injection-1)

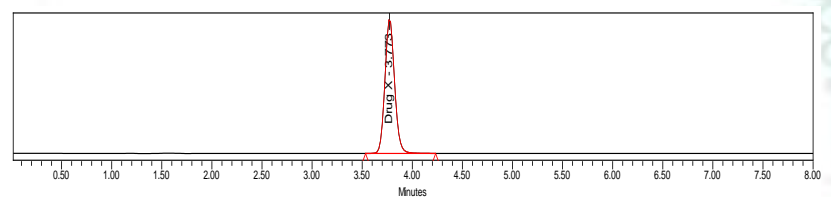

Linearity at $120 \%$ (Injection-2)

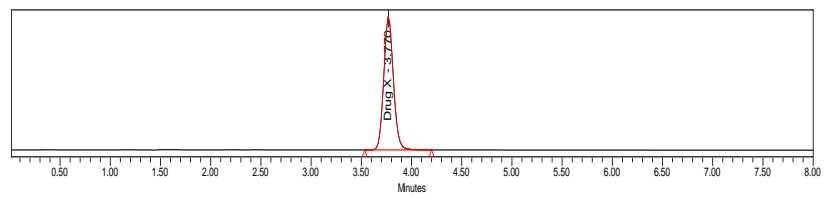

Linearity at $160 \%$ (Injection-1)

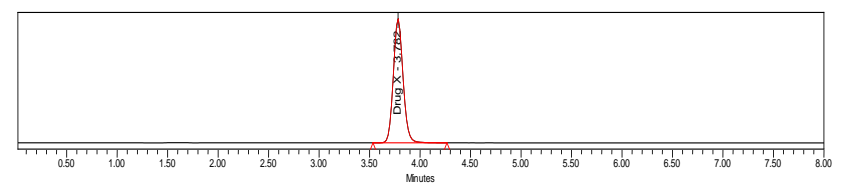

Linearity at $160 \%$ (Injection-2)

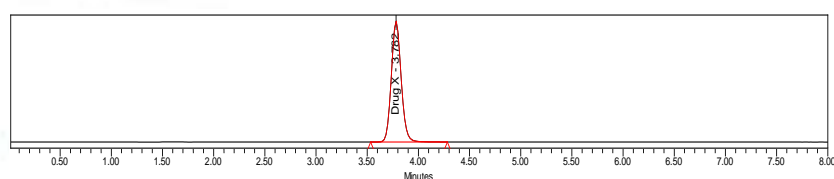

Linearity at $240 \%$ (Injection-1)

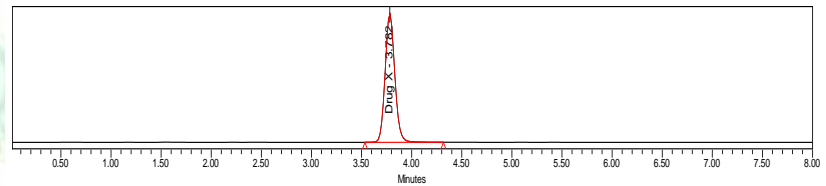

Linearity at $240 \%$ (Injection-2)

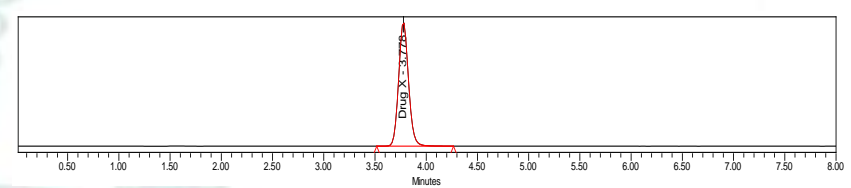

\section{Preparation of Linearity Stock Solution}

Weighed $99.52 \mathrm{gm}$ of working standard in $100 \mathrm{ml}$ volumetric flask. Added $30 \mathrm{ml}$ of methanol \& sonicated to dissolve. Made up volume with methanol. Prepared Linearity solution of 20\%, 80\%, 120\%, 160\%, 240\% by dilution of Linearity Stock solution as below

Table 15: Preparation of Linearity Stock Solution

\begin{tabular}{|c|c|c|c|c|}
\hline Sample ID & $\begin{array}{c}\text { Linearity Stock } \\
\text { Solution(mL) }\end{array}$ & Dilution $(\mathbf{m L})$ & Linearity range $(\boldsymbol{\%})$ & Conc. $(\boldsymbol{\mu g} / \mathbf{m L})$ \\
\hline Linearity - 1 & 2 & 100 & 20.1 & 15.08 \\
\hline Linearity - & 4 & 50 & 80.4 & 60.32 \\
\hline Linearity - 3 & 6 & 50 & 120.6 & 90.47 \\
\hline Linearity - 4 & 8 & 50 & 160.8 & 120.63 \\
\hline Linearity - 5 & 6 & 25 & 241.3 & 180.95 \\
\hline
\end{tabular}


Table 16: Calculation of Linearity

\begin{tabular}{|c|c|}
\hline \multicolumn{2}{|c|}{ Standard Area Counts } \\
\hline Injection & Area \\
\hline 1 & 1926300 \\
\hline 2 & 1937992 \\
\hline 3 & 1938435 \\
\hline 4 & 1934998 \\
\hline 5 & 1940483 \\
\hline Mean & $\mathbf{1 9 3 5 6 4 2}$ \\
\hline S.D. & $\mathbf{5 5 7 7 . 8}$ \\
\hline \% RSD & $\mathbf{0 . 2 9}$ \\
\hline
\end{tabular}

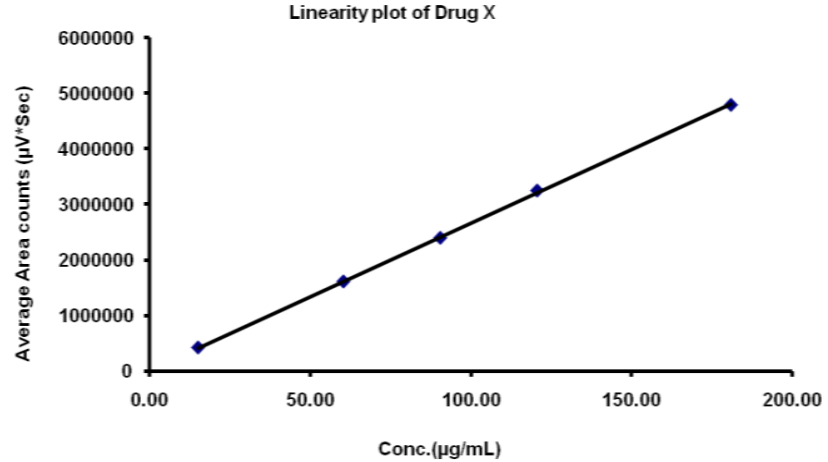

Figure 1: Linearity plot of Bosentan

Table 17: Calculation of Linearity

Molecular Wt of Bosentan: 321.82,

Molecular Wt of Bosentan salt form: 419.90,

Preparation of Linearity Stock solution: $99.52 \mathrm{gm}$ to $100 \mathrm{ml}$

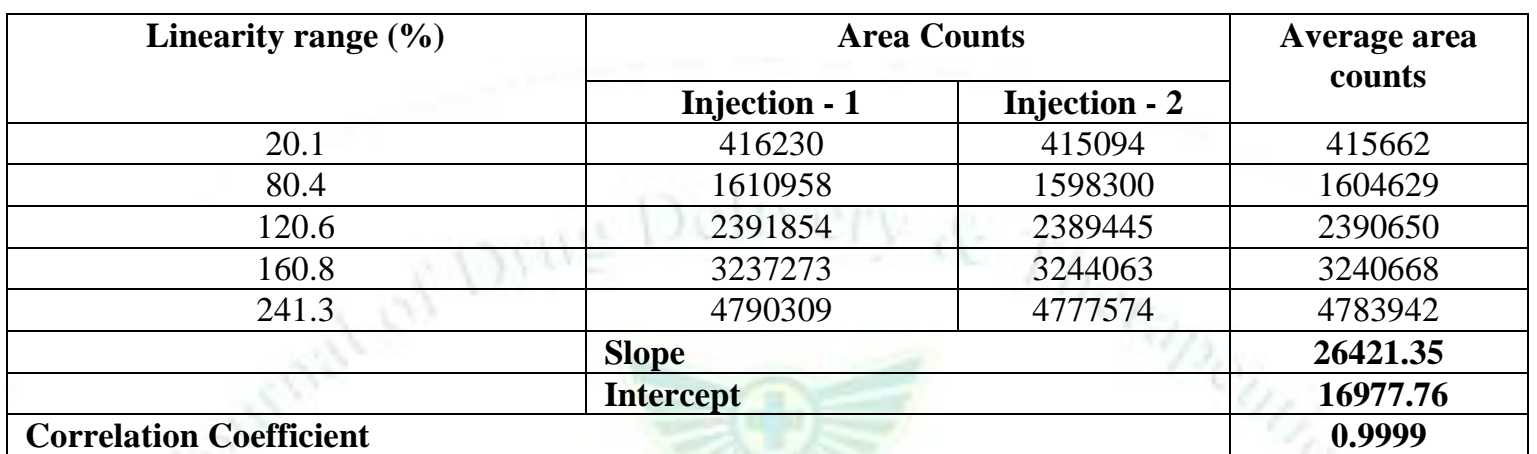

Acceptance criteria: Acceptance criteria for system suitability should pass. Correlation coefficient should not be less than 0.990 . Linearity has passed as accepted criteria.

\section{Accuracy}

Prepared system suitability solution \& diluted standard solution as per STP. Injected blank, system suitability solution $\&$ diluted standard solution as per injection sequence. Checked the acceptance criteria for system suitability.

Accuracy at $30 \%$ ( Preparation-1, Injection-1)

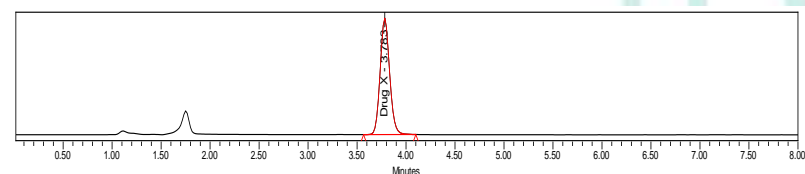

Accuracy at $30 \%$ ( Preparation-1, Injection-2)

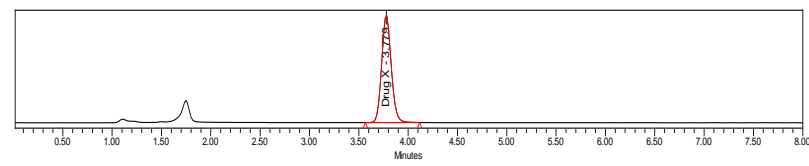

\section{Accuracy at $30 \%$ ( Preparation-2, Injection-1)}

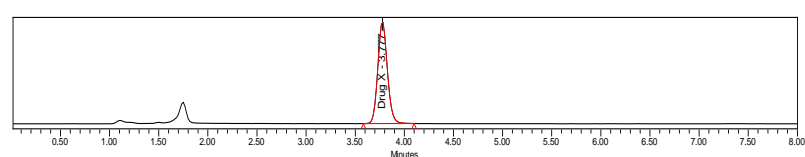

Accuracy at $30 \%$ ( Preparation-2, Injection-2)

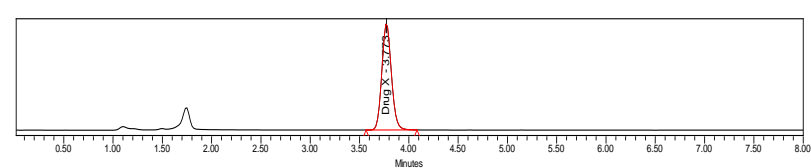

Accuracy at $30 \%$ ( Preparation-3, Injection-1)

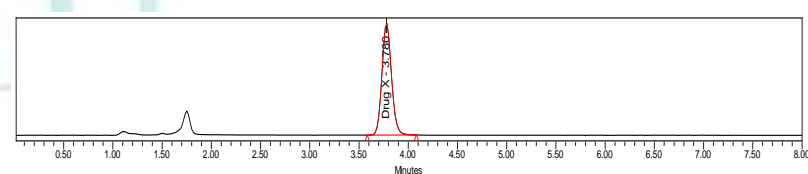

Accuracy at $30 \%$ ( Preparation-3, Injection-2)

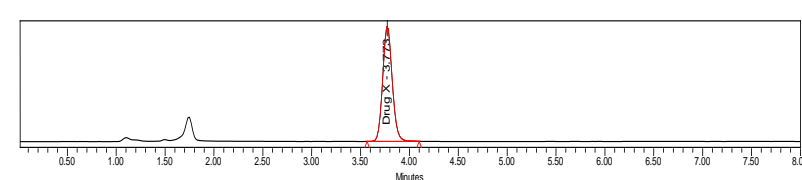

Accuracy at $100 \%$ ( Preparation-1, Injection-1)

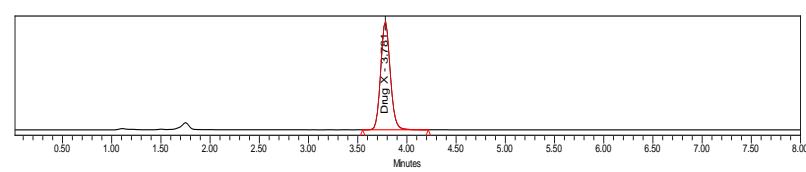

Accuracy at $100 \%$ ( Preparation-1, Injection-2)

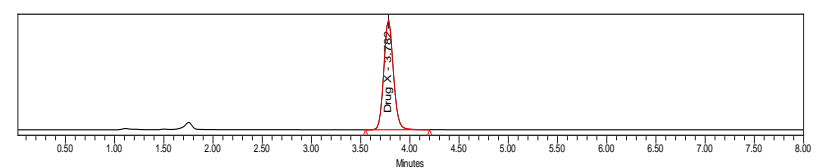


Accuracy at $100 \%$ ( Preparation-2, Injection-1)

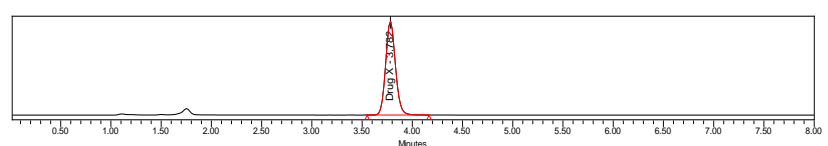

Accuracy at $100 \%$ ( Preparation-2, Injection-2)

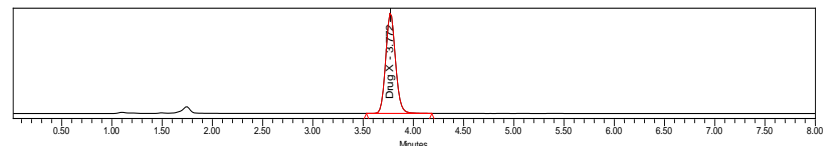

Accuracy at 100 \% ( Preparation-3, Injection-1)

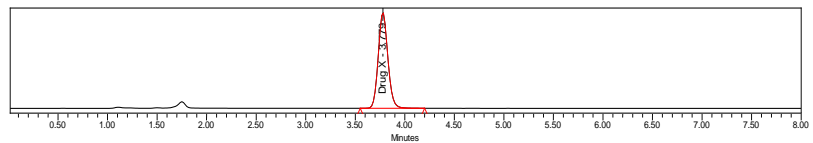

Accuracy at $100 \%$ ( Preparation-3, Injection-2)

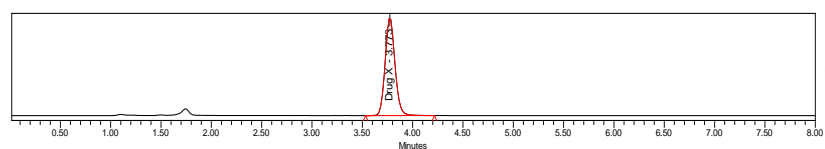

Accuracy at $200 \%$ ( Preparation-1, Injection-1)

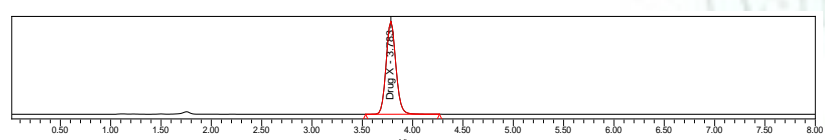

Accuracy at $200 \%$ ( Preparation-1, Injection-2)

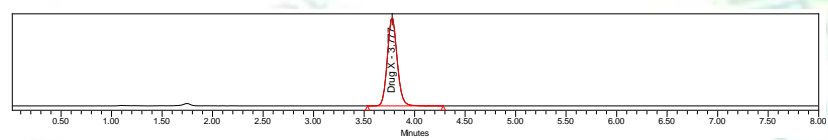

Accuracy at $200 \%$ ( Preparation-2, Injection-1)

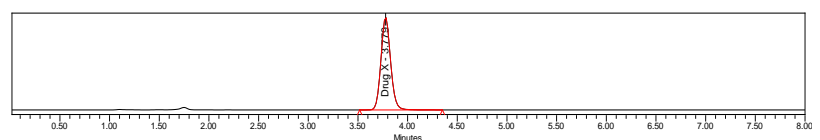

Accuracy at $200 \%$ ( Preparation-2, Injection-2)

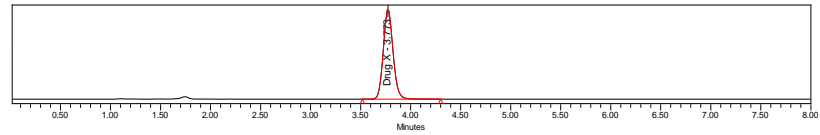

Accuracy at $200 \%$ ( Preparation-3, Injection-1)

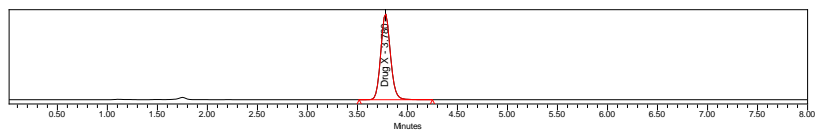

Accuracy at $200 \%$ ( Preparation-3, Injection-2)

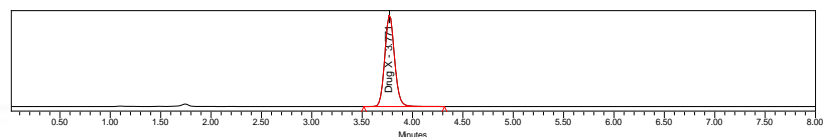

Table 18: Calculation of Accuracy

\begin{tabular}{|c|c|}
\hline \multicolumn{2}{|c|}{ Standard Area Counts } \\
\hline Injection & Area counts \\
\hline 1 & 1926300 \\
\hline 2 & 1937992 \\
\hline 3 & 1938435 \\
\hline 4 & 1934998 \\
\hline 5 & 1940483 \\
\hline Mean & $\mathbf{1 9 3 5 6 4 2}$ \\
\hline S.D. & $\mathbf{5 5 7 7 . 8}$ \\
\hline \% RSD & $\mathbf{0 . 2 9}$ \\
\hline
\end{tabular}

Table 19:

\begin{tabular}{|c|c|c|c|c|c|c|c|}
\hline \multirow[t]{2}{*}{ Sample ID } & \multirow{2}{*}{$\begin{array}{c}\text { Accuracy } \\
\text { Level }\end{array}$} & \multirow{2}{*}{$\begin{array}{l}\text { Weight taken } \\
\text { (mg) }\end{array}$} & \multirow{2}{*}{$\begin{array}{c}\text { Actual } \\
\text { Amount } \\
\text { Added (mg) }\end{array}$} & \multirow{2}{*}{$\begin{array}{c}\text { Conc. } \\
(\mu \mathrm{g} / \mathrm{mL})\end{array}$} & \multicolumn{3}{|c|}{ Area Counts } \\
\hline & & & & & Inj.1 & Inj.2 & Mean Area \\
\hline Accuracy-30\%-1 & \multirow[t]{3}{*}{29.9} & 147.91 & 112.00 & 22.40 & 586163 & 586154 & 586159 \\
\hline Accuracy-30\%-2 & & 148.01 & 112.08 & 22.42 & 586244 & 586289 & 586267 \\
\hline Accuracy-30\%-3 & & 148.23 & 112.24 & 22.45 & 586348 & 586326 & 586337 \\
\hline Accuracy-100\%-1 & \multirow[t]{3}{*}{99.5} & 492.84 & 373.19 & 74.64 & 1944499 & 1944498 & 1944499 \\
\hline Accuracy-100\%-2 & & 492.92 & 373.25 & 74.65 & 1954631 & 1954335 & 1954483 \\
\hline Accuracy-100\%-3 & & 493.10 & 373.39 & 74.68 & 1964521 & 1965421 & 1964971 \\
\hline Accuracy-200\%-1 & \multirow[t]{3}{*}{198.9} & 984.98 & 745.85 & 149.17 & 3856895 & 3856785 & 3856840 \\
\hline Accuracy-200\%-2 & & 985.19 & 746.01 & 149.20 & 3885687 & 3886789 & 3886238 \\
\hline Accuracy-200\%-3 & & 985.46 & 746.21 & 149.24 & 3918568 & 3915678 & 3917123 \\
\hline
\end{tabular}

Table 20: Accuracy recovery

\begin{tabular}{|c|c|c|c|c|c|}
\hline Sample ID & Accuracy Level & $\begin{array}{c}\text { Amount } \\
\text { Recovered (mg) }\end{array}$ & $\begin{array}{c}\% \\
\text { Recovery }\end{array}$ & & \\
\hline Accuracy-30\%-1 & \multirow{3}{*}{29.9} & 112.13 & 100.12 & Mean & 100.04 \\
\hline Accuracy-30\%-2 & & 112.15 & 100.06 & SD & 0.097 \\
\hline Accuracy-30\%-3 & & 112.16 & 99.93 & $\%$ RSD & 0.10 \\
\hline Accuracy-100\%-1 & \multirow{3}{*}{99.5} & 371.98 & 99.68 & Mean & 100.17 \\
\hline Accuracy-100\%-2 & & 373.89 & 100.17 & SD & 0.495 \\
\hline Accuracy-100\%-3 & & 375.89 & 100.67 & $\%$ RSD & 0.49 \\
\hline Accuracy-200\%-1 & \multirow{3}{*}{198.9} & 737.80 & 98.92 & Mean & 99.66 \\
\hline Accuracy-200\%-2 & & 743.43 & 99.65 & SD & 0.750 \\
\hline Accuracy-200\%-3 & & 749.33 & 100.42 & $\%$ RSD & 0.75 \\
\hline
\end{tabular}


Table 21: Compiled Recovery Data

\begin{tabular}{|c|c|c|}
\hline Sample Name & $\begin{array}{c}\text { Accuracy } \\
\text { Level }\end{array}$ & \% Recovery \\
\hline Accuracy-30\%-1 & \multirow{2}{*}{29.9} & 100.12 \\
\hline Accuracy-30\%-2 & & 100.06 \\
\hline Accuracy-30\%-3 & & 99.93 \\
\hline Accuracy-100\%-1 & \multirow{2}{*}{99.5} & 99.68 \\
\hline Accuracy-100\%-2 & & 100.17 \\
\hline Accuracy-100\%-3 & & 100.67 \\
\hline Accuracy-200\%-1 & \multirow{2}{*}{198.9} & 98.92 \\
\hline Accuracy-200\%-2 & & 99.65 \\
\hline Accuracy-200\%-3 & & 100.42 \\
\hline Overall Mean & & $\mathbf{9 9 . 9 6}$ \\
\hline Overall SD & $\mathbf{0 . 3 6 1}$ \\
\hline Overall \% RSD & $\mathbf{0 . 3 6}$ \\
\hline
\end{tabular}

\section{CONCLUSION}

An Analytical method for Assay of Bosentan Tablet was developed by Reverse phase High performance liquid chromatography by using different columns, different mobile phase ratio \& different chromatographic conditions $\&$ finally optimized using best chromatographic conditions.

The method was validated by the following parameters, system precision, method precision, accuracy, \& linearity. All these parameters have passed as per acceptance criteria.

Finally in a concise \& fruitful way, the developed method found to have several advantages over Traditional method:

$>$ The method is cheap - Only 5 Tablets require at the place of 20 Tablets.

$>$ The method is more accurate - In Direct intact method there is very less chances of contamination as compare to crush method.

$>$ The method is easy to run - Developed method is easier as compare to crush method.

$>$ The method consume Less time - Direct intact method has ability to save time of crushing, \& shorter run time in chromatography.

There are five drugs that are analyzed in this research work. All drug have the same application as antihypertensive agents to relive the blood pressure. The drug are newer in this category. The drug bosentan is angiotensin II antagonist \& latest in this category. The method for analysis is developed with high performance liquid chromatography. The method is simple, easy, accurate, sensitive, cost effective \& rapid. The method is validated according to international conference of hormonization for accuracy, precision, correctness, reproducibility, range, linearity, limit of detection, limit of quantification, robustness, ruggdness, \& system suitability parameters. The method is then applied to marketed formulations. The method of analysis of bosentan can be applied for daily routine analysis of bulk drug bosentan \& its marketed formulations.

\section{REFERENCES}

1. Weber C, Banken L, Birnboeck H, Nave S, Schulz R. The effect of bosentan on the pharmacokinetics of digoxin in healthy male subjects. Br J Clin Pharmacol. 1999, 47, 701-706.

2. Weber C, Gasser R, Hopfgartner G. Absorption, excretion, and metabolism of the endothelin receptor antagonist bosentan in healthy male subjects. Drug Metab Dispos. 1999, 27, 810-815.

3. Weber C, Schmitt R, Birnboeck H, Hopfgartner G. Pharmaco kinetics and pharmaco dynamics of the endothelin-receptor antagonist bosentan in healthy human subjects. Clin Pharmacol Ther. 1996, 60, 124-137.

4. Weber C, Schmitt R, Birnboeck H, Hopfgartner G, Eggers H. Multiple-dose pharmacokinetics, safety, and tolerability of bosentan, an endothelin receptor antagonist, in healthy male volunteers. J Clin Pharmacol. 1999, 39, 703-714.

5. O' Neil MJ, editor. The Merck Index: An Encyclopedia of Chemicals, Drug and Biologicals. 2006.

6. Dell D, Lausecker B, Hopfgartner G, Giersbergen P L M V and Dingemanse J. Evolving bio analytical methods for the cardiovascular drug bosentan. Chromatographia. 2002, 55, Supplement 1, S115-119.

7. Chavanpatil M D, Rajeshkumar N V, Gulati A. Determination of endothelin antagonist BMS182874 in plasma by highperformance liquid chromatography. Die Pharmazie. 2006, 61, 525-527.

8. Karnaker Reddy T, Younus Md, Ravindra Reddy.Y, Ashwini kumar G, Sravan S. RP-HPLC method development and validation of bosentan drug present in tablets. Int $\mathrm{J}$ Pharm Tech. 2010, 2, 577-587.

9. Ashwini G, Aravindsai N, Karnaker Reddy T, Kumar A Estimation of Febuxostat drug present in formulation by RPHPLC. Journal of Pharmacy Research, 2012; 5(2): 1224- 1227

10. Agarwal A, Tiwari S, Nagariya K, Method development and its validation for quantitative simultaneous determination of latanoprost, timolol and benzalkonium chloride in ophthalmic solution by RP-HPLC, Journal of Drug Delivery \& Therapeutics; 2013; 3(2):26-30

11. Shah J, Parmar K, Development \& validation of HPLC method for analysis of some an-tihypertensive agents in their pharmaceutical dosage forms, Journal of Drug Delivery \& Therapeutics; 2014; 4(2):12-15

12. Bhowmick M, Bhowmick P, Sengodan T, Thangavel S, Development and validation of bioanalytical RP HPLC method for the estimation of metoprolol tartrate in rabbit plasma after transdermal and oral administration: application in pharmacokinetic studies, Journal of Drug Delivery \& Therapeutics; 2015; 5(4):43-53 